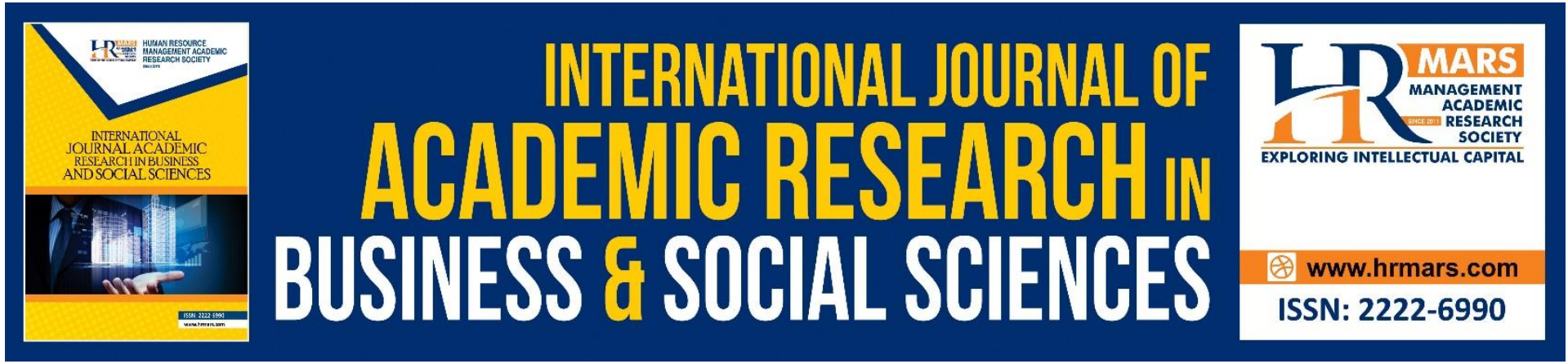

\title{
Level of Inclination and Interest of Kuala Sungai Baru Muslim Community towards Learning Arabic in The Mosque
}

Nuraznan Jaafar, Noor Adawiyah Ahmad Radzi, Mohd Zahimie Mohd Dzahid, Muhammad Yasin Omar Mokhtar \& Fadzly bin Ab. Rahim

To Link this Article: http://dx.doi.org/10.6007/IJARBSS/v11-i6/10257 DOI:10.6007/IJARBSS/v11-i6/10257

Received: 18 April 2021, Revised: 20 May 2021, Accepted: 11 June 2021

Published Online: 24 June 2021

In-Text Citation: (Jaafar et al., 2021)

To Cite this Article: Jaafar, N., Radzi, N. A. A., Dzahid, M. Z. M., Mokhtar, M. Y. O., \& Rahim, F. bin A. (2021). Level of Inclination and Interest of Kuala Sungai Baru Muslim Community towards Learning Arabic in The Mosque. International Journal of Academic Research in Business and Social Sciences, 11(6), 1221-1229.

Copyright: (c) 2021 The Author(s)

Published by Human Resource Management Academic Research Society (www.hrmars.com)

This article is published under the Creative Commons Attribution (CC BY 4.0) license. Anyone may reproduce, distribute, translate and create derivative works of this article (for both commercial and non-commercial purposes), subject to full attribution to the original publication and authors. The full terms of this license may be seen

at: http://creativecommons.org/licences/by/4.0/legalcode

Vol. 11, No. 6, 2021, Pg. 1221 - 1229

http://hrmars.com/index.php/pages/detail/IJARBSS

JOURNAL HOMEPAGE

Full Terms \& Conditions of access and use can be found at http://hrmars.com/index.php/pages/detail/publication-ethics 


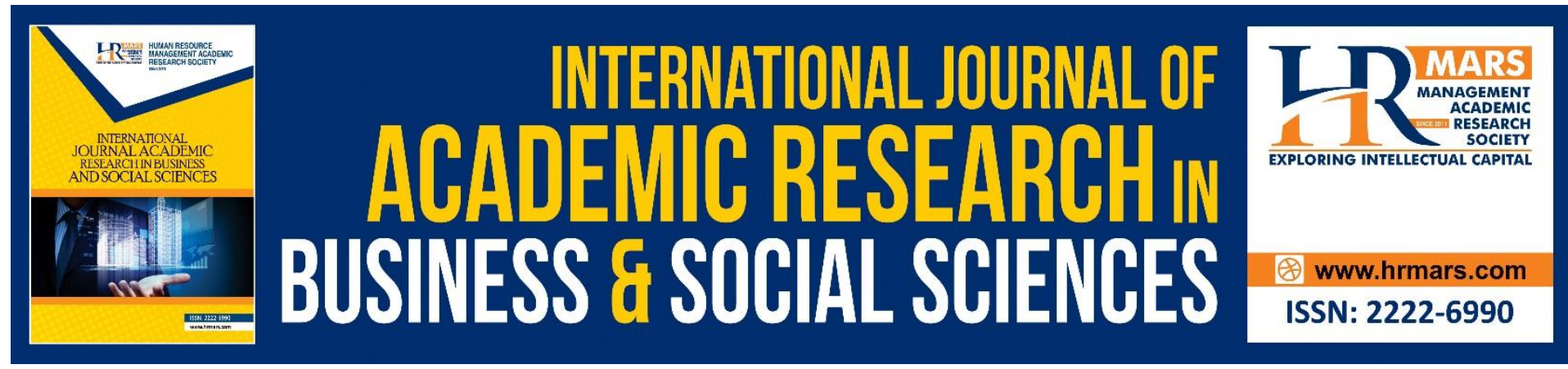

\title{
Level of Inclination and Interest of Kuala Sungai Baru Muslim Community towards Learning Arabic in The Mosque
}

\author{
${ }^{1}$ Nuraznan Jaafar, ${ }^{2}$ Noor Adawiyah Ahmad Radzi, ${ }^{3}$ Mohd \\ Zahimie Mohd Dzahid, ${ }^{4}$ Muhammad Yasin Omar Mokhtar \& \\ ${ }^{5}$ Fadzly bin Ab. Rahim \\ 1, 2,3, ${ }^{5}$ Faculty of Language and Education Kolej Universiti Islam Melaka, Malaysia, ${ }^{4}$ Research \\ Management Centre Kolej Universiti Islam Melaka, Malaysia
}

\begin{abstract}
No doubt that the Arabic language is now gaining popularity among people of various religions and nations, particularly Muslim Malay community in Malaysia. Moreover, the Arabic language itself is very synonymous with the study of the Quran which is written in Arabic and has even become the way of life for Muslims around the world. Therefore, this study aims to identify the level of inclination and interest of the Kuala Sungai Baru Muslim Community (MIKSB) towards learning Arabic in the mosque. The objective of this study is to identify the level of inclination, interest and also to identify the level of awareness of the Kuala Sungai Baru Muslim Community (MIKSB) towards learning Arabic in the mosque. This quantitative study involved a total of 74 respondents from nine mosques selected by a simple random sample by applying the Tabachnick and Fidell (2007) Technique. The study also will use questionnaires instrument to obtain data. The collected data will then be analysed descriptively for both objectives. The findings of the study showed that the overall mean of the respondents' inclination level and interest of the Kuala Sungai Baru Muslim Community (MIKSB) towards learning Arabic in the mosque was at a high level (mean =4.31). Meanwhile, the level of awareness of Kuala Sungai Baru Muslim Community (MIKSB) in learning Arabic at mosque also showed that the mean was at a high level (mean $=4.36$ ). Therefore, through these findings, the researcher suggested that Arabic language classes be provided by the mosque management to facilitate the local community in learning Arabic.
\end{abstract}

Keywords: Arabic Language Learning, Inclination, Awareness, Community

\section{Introduction}

Arabic learning in Malaysia is growing through various mediums that have been developed from time to time. In the past, the learning of Arabic was only concentrated in mosques and selected religious schools, but in the current century, it has become more advanced and highly regarded in all parts of the world, especially in our country, Malaysia. However, the progress in Arabic Language which was seen outstanding in most of our Educational Institutions in Malaysia, we are still lagging behind in implementing this tendency Arabic learning in the 
mosque among Malay Muslims communities in particular. Decades ago, Arabic was synonymous with mosques, but now it is fading. Only a few mosques with adequate facilities are able to create special Arabic language classes for the general public.

A study by Husin (2014) states that the mosque is seen not only as a place to perform specific acts of worship in Islam, but it also serves as a center for the dissemination of knowledge for the Muslim community. Part of the management of mosques in Malaysia in the current era has provided various facilities and infrastructure to the congregation in taking short courses in Arabic. It is seen as a driving force in efforts to prosper the mosque as an "Arabic Language Zone"; a place to learn, use and reviving the language of the Quran so that Muslims can master it. While Yusof (2008) in his study found that many mosques and suraus have provided chairs and tables for teachers to sit so that they look taller and can be seen more clearly compared to teachers sitting cross -legged on the floor.

We cannot deny that Arabic is one of the branches of knowledge in Islam that should be taught in the mosque apart from another religious knowledge. This is because almost all religious studies made in mosques have to do with the Arabic language, even the Quran itself is written in Arabic. On that basis, the learning of the Arabic language for the Muslim community in Malaysia should be evaluated so that the community is educated and not left behind in understanding the knowledge they learn in the mosque.

Preferences and interests in learning Arabic should be fostered among the community and it should start from the mosque were the Muslim community congregate to perform prayer daily in addition to other religious programs that were held in the mosque. Learning Arabic in the mosque also will to some extent lead to the awareness of the congregation and it is at the same time able to educate family institutions inclined towards learning Arabic. At the same time, the concept of understanding in worship can be enhanced by learning the basics of the Arabic language. Every recitation of the Quran, recitation in salat, prayer recitation and fardhu ain obligations are all written and recited in Arabic. It can be said that almost all Muslims in Malaysia only know how to read without understanding the meaning behind it. Therefore, if the learning of Arabic is nurtured, it will give more appreciation in practice of Islam among Muslim and create a society that is more moral, disciplined and leads towards a religious life. In conclusion, the tendency and interest of the Muslim community towards learning Arabic needs to be nurtured so that the power of knowledge and thinking grows with the passage of time. Therefore, the role of the mosque in conducting appropriate Arabic language programs and classes cannot be denied. Even mosques need to play an important role and serve as a place for the public to learn Arabic consistently.

\section{Research Problems}

The authority of the mosque institution has a very big role to play for Muslim community. This is because the institution of the mosque is a symbol of Islamic teachings since the time of the Prophet Muhammad. The role of the mosque is to unite Muslims in various aspects of life. It is common that the mosque has many functions and is a reference point for Muslims in various matters. Among its functions are as a reference center for economic development, social institutions, knowledge dissemination center and etc. (Rosmawati and Syafiqah, 2016). This study focuses on the aspect of learning Arabic in the mosque. The lack of classes and exposure of Arabic language learning for the Kuala Sungai Baru Muslim Community (MIKSB) in the mosque is a strong factor in this study. The results of researchers survey in 10 mosques at Kuala Sungai Baru found that among the studies of Islamic knowledge that are the focus of most mosque management are the study of the Quran, Hadith Nabawi, Tafsir al-Quran, Fiqh 
\& Usul al-Fiqh, Morals and Sirah Nabawiah, Although some of these knowledge are taught through books written in Arabic, but the learning of Arabic itself in particular is still not established in most mosques whereas if the learning of Arabic is revealed specifically, by learning the basics of Arabic related to daily worship, it is directly and indirectly able to strengthen the process of daily prayer, understand what is read and practice, will increase the appreciation of Islam. The inclination, interest and love of knowledge will result through the process of education and effective delivery of knowledge, and it of course starts from learning in the Mosque because that is where the Muslim community gathers to perform daily worship.

\section{Research Objective}

i. To identify the level of inclination and interest of the Kuala Sungai Baru Muslim Community towards learning Arabic in the mosque.

ii. To identify the level of awareness of the Kuala Sungai Baru Muslim Community on learning Arabic in the mosque.

\section{The importance of the Study}

This study was conducted to identify the level of inclination and interest of the Kuala Sungai Baru Muslim community towards learning Arabic in the mosque. This is because the mosque is a very important institution for Muslims. In addition, the findings of this study can help the mosque management to formulate effective strategies in enlivening the activities in the mosque.

\section{Literature Review}

The tendency and interest in learning Arabic involve in every group of society in accordance with their education which begins from the kindergarten to university level. Arabic language education has become an important thing in not only producing knowledgeable people in Arabic but as what we know the use of Arabic language is now a necessity in the local community.

\section{Definition of Inclination and Awareness}

The definition of inclination according to the Oxford Dictionary a person's natural tendency or urge to act or feel in a particular way: a disposition. While the definition of consciousness according to the Oxford Dictionary means the subject of being aware of and responsive to one's surrounding.

\section{Learning Arabic in the Mosque}

Mosques are considered as intermediary institutions in the educational process. It is not seen only to perform specific iabadah only, in fact the mosque is an institution that plays an important role in various aspects. The mosque serves as a place for the public regardless of age and level of education in learning religious knowledge. In the Middle East, Arabic language learning is best applied because they are aware of the importance of Arabic to understand the Quran and communicate with outsiders (Rofishah and Burhanuddin, 2015).

\section{Tendency and Interest in Learning Arabic}

Shahrizal (2013) study has made a different study by linking the community by linking the learning of Arabic to the public for the purpose of worship. It is undeniable that even a 
necessity nowadays in increasing the appreciation of Islam, people need to learn Arabic in accordance with the purpose of worship performed every day. According to him, all acts of worship of Muslims are not exempt from the use of Arabic, in fact it is a condition that an act of worship is accepted, especially those involving prayer and pilgrimage. This makes the Arabic language very synonymous with Islam and its people. The diversity of races and languages of Muslims around the world is the main basis for the need to learn Arabic, especially for the purpose of worship. The results showed that the majority of the public recognizes the importance of learning Arabic for the Muslim community, especially to understand the basic readings in worship. Various suggestions were also submitted by the respondents to improve the quality of learning Arabic.

In addition, the tendency to learn Arabic is also found among imams. A study related to "Imam's Attitude Towards Learning Arabic for the Purpose of Career Development" was conducted by Hidayati (2014). According to him, the Imam of the Mosque is an important individual who is considered by the community to be able to speak Arabic well. The Imams not only need to know about prayers but they also need to understand the meaning of words and know the errors of the verses recited during prayers, supplications, sermons and so on. In addition, the study of Kasran (2015) found that there are three (3) main factors of senior citizens learning Arabic, namely religious factors, communication factors and social factors. Regarding learning materials, senior citizens tend to learn topics related to religious themes, communication themes, language elements such as phonology, morphology, syntax, vocabulary and the beauty of language and language skills elements such as reading, speaking, listening and writing. This study has successfully proved the importance of conducting needs analysis because it has proven successful in revealing the needs and desires of learning Arabic among the elderly that can be realized in building a learning program for the group.

\section{Awareness of learning Arabic}

Redzaudin (2016) study entitled The Level of Public Awareness Towards Learning Arabic in the Mosque states that usually the Arabic language is taught and learned in educational institutions; primary schools, secondary schools and tertiary institutions. However, Arabic is also taught and learned among the public in mosques or suraus. The findings showed that the overall analysis of "awareness" items recorded a consistently high percentage of answers, while the overall analysis of "implementation" items showed a different percentage for each item consisting of desire and willingness to learn, appropriate teaching and learning methods and teaching aids used.

In addition, the study of Afifah and Suhaila (2014) found that the aspect of self -awareness $(57.4 \%)$ is also a factor to the learning of Arabic among the general public. Another factor that drives the public interested in learning Arabic is their desire to communicate in Arabic (54.9\%). Researchers are of the view that this factor will peak when communication is associated with performing umrah and hajj. In addition, the communication aspect will be among the main factors in learning Arabic when it is associated with the career profession. Diplomats or certain individuals who are assigned to go abroad, especially to Arab countries, will certainly choose the aspect of communication as the main purpose of learning Arabic.

The awareness of an individual can be nurtured through their role in a community. The community has a major role to play in the success of Arabic language education and Islamic education in the 21st century. At home, parents can play the role of communicating with children in simple Arabic dialogue. Norfaezah (2016) says that parents need to instill good 
values in children through Arabic words that carry the value of manners. For example using Hayya (حي) when inviting a child to pray or In Shaa Allah (إن شاء الله) when promising a child (Norfaezah, 2018).

In addition, the community can also contribute towards the success of learning Arabic in the 21st Century. Among others, through collaborative aspects by organizing community activities such as gotong- royong with locals can strengthen friendship and greet each other can also be inserted elements of Arabic. Weekend sports activities can also strengthen the brotherhood in addition to learning Arabic indirectly. In addition, by holding Arabic language camps for the local community or mountain climbing activities, Arabic rehlah can help and bring the nature -loving community closer and is interspersed with indirect Arabic language learning (Norfaezah, 2018).

In conclusion, the learning of Arabic should be expanded among the mosque community based on their level of inclination and awareness. This is because, the study of religious knowledge delivered by the teachers in the mosque will use verses of the Quran and hadith which is in Arabic. Therefore, through Arabic learning with a specific purpose can help the community in better understanding and learning in other way it will transformed the community into Arabic Knowledgeable savvy community. In fact, knowledge of the Arabic language will also be extended to all walks of life.

\section{Methodology}

Instrument used

Sampling

The study involved 66 respondents from the congregation of the mosque in Kuala Sungai Melaka recently. Researchers have focused on the study of Malay Muslims. The method used is according to the technique of Tabachnick and Fidell (2007) which is a simple random sample where all mosque congregations around Kuala Sungai Baru have more equal opportunities to be selected as a sample.

$$
\begin{gathered}
N>50+8(\mathrm{~m}) \\
N=\text { sampling } \\
M=\text { number of variables } \\
N>50+8(2)=66 \text { people }
\end{gathered}
$$

Therefore, in total the researcher selected a total of 74 respondents randomly grouped in this study. The test tools used and the number of items available in each question are stated in the table provided below. 
Table: Study instruments

\begin{tabular}{|l|c|}
\hline \multicolumn{1}{|c|}{ Aspect } & $\begin{array}{c}\text { Number of } \\
\text { Questions }\end{array}$ \\
\hline Inclinations \& Interests & 5 \\
\hline awareness & 5 \\
\hline
\end{tabular}

Reliability

\section{Findings}

\section{Mean Level Analysis by Section}

Table 2 : Interpretation of Mean Scores (Davis, 1971)

\begin{tabular}{|c|c|}
\hline Statement & Mean scores \\
\hline High & $3.68-5.00$ \\
\hline Medium & $2.34-3.67$ \\
\hline Low & $1.00-2.33$ \\
\hline
\end{tabular}

Table 3: Analysis of the Mean Variables

\begin{tabular}{|c|c|c|}
\hline VARIABLES & MEAN & LEVELS \\
\hline Inclinations \& Interests & 4.31 & High \\
\hline Awareness & 4.36 & High \\
\hline
\end{tabular}

For the level analysis of each section, the Interpretation of Mean Scores (Davis, 1971) will be used by the researcher. The level of students' perception of the level of inclination and interest in the Arabic language shows that the overall mean of the respondents is at a high level (mean = 4.31). As for the perception of the level of awareness of the importance of the Arabic language, the mean is at a high level (mean $=4.36$ ). As for the level of students' perception of VARIABLE c, the mean is at a moderate level (mean = 3.89). The last part, the level of students' perception of VARIABLE D, shows that the mean is at a high level (mean = 4.28). In conclusion all perceptions show that the mean is at a moderate level

\section{Discussions}

The analysis of the study that has been conducted shows that all the variables studied are at a high mean level. This study is supported by several studies that have been conducted by several previous researchers who conducted a study on the inclination and interest of the Muslim community in the mosque towards learning Arabic. The first is a study from Husin (2014). His study showed that the mosque also serves as a medium of learning Arabic for the locals. Apart from that, a study conducted by Yusof (2008) in his study found that many mosques and suraus have provided chairs and tables for teachers to sit so that they look taller and can be seen more clearly compared to teachers sitting cross -legged on the floor. In the 
eyes of the congregation nowadays, they come to the mosque not only for congregational equity but, they want a useful filling. Among them include reading the Quran, listening to lectures or learning Arabic. Therefore, the management of the mosque should take the opportunity to enliven the mosque through knowledge-filling activities such as increasing the number of Arabic language classes.

\section{Conclusion}

Learning Arabic is very important to the Muslim Malay community affairs for several major Muslim worship such as prayer, reading the al-Qur'an and remembrance implemented using Arabic. There is even an act of worship that is void by itself if you use a language other than Arabic as in matters of prayer. It actually shows the mosque should be back great responsibility to organize classes Arabic Malay Muslim community. This role is not foreign to this age because mosques once played that role. Furthermore, this role will definitely get full support from various parties such as religious authorities. However, to ensure that the objectives are achieved, a further study needs to be conducted specifically on the appropriate syllabus content and compiled as an Arabic language learning module to the local community.

\section{Acknowledgement}

This research received no specific grant from any funding agency in the public, commercial or not-for-profit sectors.

\section{References}

Abdullah, A. B., Sulaiman, A. A., \& Abdullah, W. I W. (2015). Faktor-faktor yang Mempengaruhi Motivasi Terhadap pembelajaran Bahasa Arab. Jurnal Islam dan Masyarakat Kontemporari. ISSN 2289 6325. Bil 102015.

Fadzil, N. A., \& Suhaila, Z. H. A. (2014). Faktor Pembelajaran Bahasa Arab Dalam Kalangan Orang Awam di Malaysia. Pengajaran dan Pembelajaran Bahasa dan Sastera Arab. 2014. HIm. 123-131.

Ghazali, A. R., Hussin, M. N., Latif, K. A. A., Ismail, M. R., Shatar, W. M A. A., \& Man, S. (2016). Tahap Kesedaran Masyarakat Terhadap Pembelajaran Bahasa Arab Di Masjid. e-Journal of Arabic Studies \& Islamic Civilization e-ISSN: 2289-6759 Volume 3. HIm. 68- 75.

Hamidin, N. M., \& Ismail, W. (2018). Peranan Komuniti Terhadap Pembelajaran Bahasa Arab Abad Ke 21. e-Prosiding Persidangan Antarabangsa Sains Sosial dan Kemanusiaan 2018. HIm. $702-712$.

Hussin, M. N., Ghazali, A. R., \& Ismail, M. R. (2014). Masjid dan Pengajian Bhs Arab: Kajian di Gombak Selangor. Proceeding of the International Conference on Masjid, Zakat and Waqf (IMAF 2014) (e-ISBN 978-967-13087-1-4). 1-2 December 2014, Kuala Lumpur, MALAYSIA. HIm. 189-193.

Karim, N. R. A \& Syafiqah, S. (2016). Faktor Yang Mempengaruhi Kecenderungan Masyarakat Dalam Mengimarahkan Masjid. Proceedings On International Conference On Islamic Education and Research 2016 (ICER 2016), $5^{\text {th }}-6^{\text {th }}$ Dec 2016.

Kasran, H., Mezah, C. R., \& Mustapha, N. F. (2015). Analisis Keperluan Pembelajaran Bahasa Arab Dalam Kalangan Warga Emas. E-Journal of Arabic Studies \& Islamic Civilization EISSN: 2289-6759 Volume 2. HIm. 101-115.

Nasir, M. S., Yahaya, M. F., \& Sahrir, M. S. (2013). Pembelajaran Bahasa Arab Untuk Tujuan Ibadah Sebagai Satu Keperluan Bagi Masyarakat Awam. Conference: Malaysia International Conference on Foreign Languages (MICFL 2013) Volume 1. 
Othman, M. F. (2008). Menjana Kelahiran Khaira Ummah Melalui Institusi Masjid. Kertas kerja seminar Pemantapan Institusi Masjid : Wasilah Ke Arah Kecemerlangan Umat. INMIND.

Rafy, N. H. M., \& Arifin, Z. ( 2014). Sikap Imam Terhadap Pembelajaran Bahasa Arab Tujuan Pembangunan Kerjaya. Prosiding Seminar Pengajaran \& Pembelajaran Bahasa Arab ISBN 978-967-5478-78-9. HIm. 261-267.

Rashid, R., \& Abdullah, B. (2015). Pengajaran Bahasa Arab di masjid sebagai Pusat Pembelajaran Sepanjang hayat. Prosiding persidangan Kebangsaan Bahasa Arab (NCAL 2015). 